\title{
PSEUDOANEURISMA ARTÉRIA FEMORAL PÓS-ANGIOPLASTIA PERCUTÂNEA DE ARTÉRIA RENAL
}

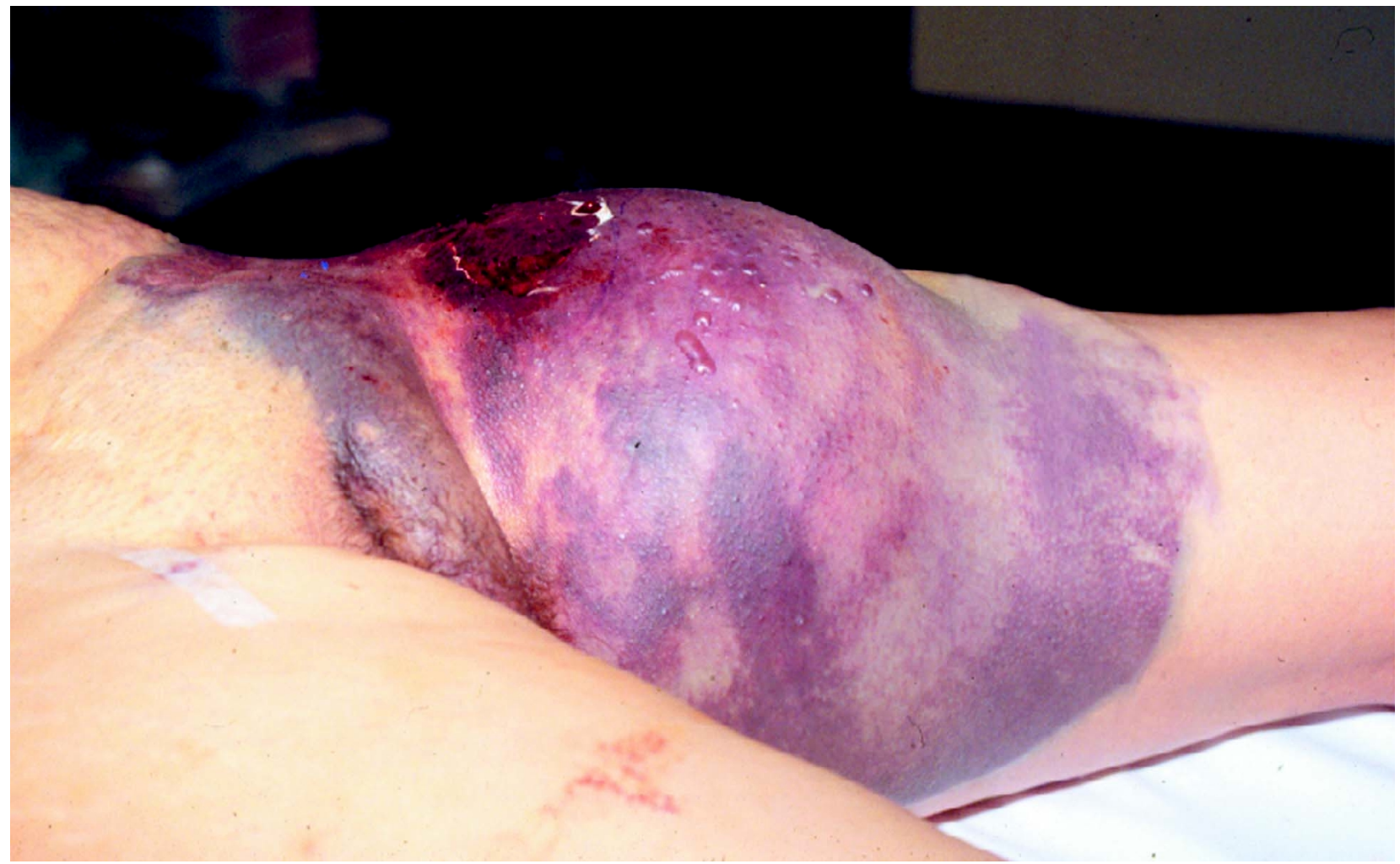

Este volumoso pseudoaneurisma de artéria femoral, com estiramento de pele e formação de bolhas, ocorreu após uma angioplastia percutânea de artéria renal por estenose e hipertensão renovascular. Ohematoma ocorreu cerca de 90 minutos após a intervenção, com a paciente já no quarto. Pseudoaneurisma com hematoma desta magnitude deve ser imediatamente removido e a artéria suturada. Pseudoaneurismas menores podem ser tratados pela compressão direcionada pelo transdutor de ultra-som, evitando muitas vezes o tratamento cirúrgico.

Luiz Francisco Poli de Figueiredo

Newton Barros JR

Disciplina de Cirurgia Vascular - Universidade federal de São Paulo - Escola Paulista de Medicina - São Paulo - SP 